\title{
PIONEER
}

VOLUME 10, Issue 2, December 2018: 43 - 53

\section{THE ANALYSIS OF METAPHOR TRANSLATION IN THE NOVEL ANGELS AND DEMONS BY DAN BROWN}

\author{
Riski Nur Ilahi \\ University of Abdurachman Saleh Situbondo \\ riskibintang03@gmail.com \\ Sufil Lailiyah \\ University of Abdurachman Saleh Situbondo \\ sufil.lailiyah@gmail.com \\ Ahmad Yusuf Firdaus \\ University of Abdurachman Saleh Situbondo \\ fyrdhaus@gmail.com
}

\begin{abstract}
This research analyzed metaphor translation in the novel of Angels and Demons with the purposes to analyzing the technique of translation and to know the quality of metaphor translation found in the novel Angels and Demons. The data were analyzed by using the theory of metaphor by Larson (1998), technique of translation used theory of Molina and Albir (2002) and quality of translation used Translation Quality Assessment theory by Nababan (2012). The analysis started by analyzing metaphorical expression, classifying the technique of translation and identifying the quality of translation based on the theory that was use for this research. The findings revealed that there were 119 metaphor expressions with 84 live metaphors and 35 dead metaphors. The metaphor translation used nine techniques of translation and the quality of metaphor translation was qualified by the assessment 2.90 .
\end{abstract}

Keywords: metaphor, translation technique, translation quality

\section{INTRODUCTION}

Metaphor was part of figurative language. Metaphor was a figure of speech in which a word or expression normally used one object and action which extended to another. According to Larson (1998:274), there were two types of metaphor. That was dead metaphor and live metaphor. Dead metaphor was a figure of speech which has lost the original imagery of its meaning due to extensive, repetitive, and popular usage such as the 
expression "to kick the bucket". Live metaphor was defined as a metaphor which could be identified by its readers after they gave special attention to the primary meaning of the words which were used metaphorically. For example, of the expression "God does not play dice with the universe". This research explained about translation technique based on Molina and Albir (2002) as one of the theories used in this research. Quality of translation was rated by three aspects, namely accuracy, acceptability, and readability in the Translation Quality Assessment (Nababan et al, 2012). The three aspects used in this research to rate the quality of metaphor translation.

The researchers conducted this research based on some research problems and objectives. The research problems were what metaphor expressions found in Angels and Demons and the translated version of the novel, what translation techniques used to translate metaphors found in Angels and Demons and the translated version of the novel, and how was the quality of the translated metaphors found in Malaikat dan Iblis as the translated novel of Angels and Demons. This study to describe the metaphor expression found in the novel Angels and Demons, to classify technique of translation and to explain the quality of translation of the metaphor translation in Malaikat dan Iblis as the translated novel of Angels and Demons. This research focused on explaining the translation of metaphorical expressions found in the novel Angels and Demons by Dan Brown and Malaikat dan Iblis written by Isma B. Koesalamwardi. This research used theory of metaphor by Larson (1998), technique of translation theory by Molina and Albir (2002), and quality of translation in the Translation Quality Assessment theory by Nababan (2012).

\section{Figurative Language}

Figurative language is good languages that used to increase the effect of introduction and compare a certain thing with another which more general. In the other words, the utilizing of figurative language can change and appear a certain connotation (Dale et alin Tarigan, 1990:112). According to X.J. Kennedy, (1983: 481), figurative language consists of comparative, contradictive, relation and repetition figurative language. Comparative figurative language consists of personification, metaphor, and simile. The researchers discussed about metaphor which was included into comparison of figurative 
language.

\section{Metaphor}

Metaphor was from Greek, namely metaphora which meant "to move"; Meta meant "above, more than," and pherein meant "to bring." Metaphor implied analogies that identified one object with another and ascribed to the first one more qualities or characteristics of the second referential element. According to Larson (1998:274), there were two types of metaphor, dead metaphor and live metaphor. Live metaphor was defined as a metaphor which identified by its readers after they gave special attention to the primary meaning of the words which were used metaphorically. For example: "John's decision is a nightmare for his brother". To understand the metaphor above, special attention has to be paid to the primary meaning of "nightmare". Relating to the topic, "John's decision", the readers will capture the message of this sentence, that the decision, whatever it was something that made her brother unhappy. Dead metaphors were those which were a part of constructions of lexicon of the language. When they used, the person who listens or reads does not think about the primary sense of the words, but only the idiomatic sense directly. The dead metaphor was commonly defined as a metaphor which has lost its metaphorical sense. For example; "Leg of the table" is an idiom. There is a comparison between the table and the leg of person or animal. Such idiom is called a dead metaphor because the reader did not think of the comparison on which it was based.

\section{Translation}

According to Toury in Venuti (2002:496), translation is a communication in translated messages within a certain cultural-linguistics system, with all relevant consequences for the decomposition of the source message, the establishment of the invariant, its transfer across the cultural-linguistics border and the recomposition of the target language.

\section{Technique of translation}

The approach of technique of translation as is illustrated by Molina (1998) quoted in Lucia Molina and Hurtado (2002:509), there are 18 techniques of translation, they are 
literal, calque, borrowing, adaptation, amplification, compensation, description, discursive creation, established equivalence, generalization, linguistic amplification, linguistic compression, modulation, particularization, reduction, substitution, transposition and variation.

\section{Quality of translation}

Honig (1997) in Nababan (2012:48) says that research of translation is repeatedly relate to the case of quality of translation. Nababan et al (2012:49) mentions that quality of translation definite by level of accuracy in transfer message or meaning, level of acceptability from source language into target language and level of readability of the translation text.

\section{Novel of Angels and Demons}

Dan Brown was the author of numerous \#1 bestselling novels, including The Da Vinci Code, which has become one of the bestselling novels of all time as well as the subject of intellectual debate among readers and scholars. This novel told about the illumination brotherhood who attacked Chruch and he want to create the world with the antimaterial, rejected science and religion.

\section{Previous Studies}

The first, Anwar's thesis (2015) entitled "An Analysis of Metaphor in American Gods Novel by Neil Giman”. The researcher took a metaphor in American Gods novel Gaiman Neil as the topic of the study. There were some steps to analyze the data, they were identified the types and meaning of metaphor according to Larson's classification, identified the figurative language of metaphor and used connotative meaning, and the last is interpreted the data.

The second was Qomariah's thesis (2015) entitled “The Analysis of Personification Translation in the Novel of Angels and Demons". The researcher took about personification translation in novel entitled, Angels and Demons by Dan Brown with its translation novel Malaikat dan Iblis by analyzing the technique of the personification translation, quality of 
the translation and the impacts of the technique translation to the quality translation. The analysis started by analyzing the translation technique that was confronted by Molina and Albir (2002) and Moentaha (2006). Then, it continued by analyzing the data of quality of the text translation which was obtained from the result of assessment in accuracy, acceptability, and readability.

The third was Thahara's thesis (2014) entitled "Analisis Terjemahan Simile dalam Novel Angels \& Demons ke dalam Malaikat \& Iblis". The researcher took about simile translation in the novel Angels and Demons by Dan Brown with its translation novel Malaikat dan Iblis. The reseacher was identified the technique translation according to Nababan.

Based on the previous studies, it was clear that the researchers examined the metaphor translation of the Angels and Demons because the research on metaphor translation has never been discussed and in this novel have many metaphor expressions for the style of language. This case made the researchers interested in doing this research entitled, "The Analysis of Metaphor Translation in the Novel Angels and Demons by Dan Brown“.

\section{METHODOLOGY}

This research used a qualitative research in analyzing metaphor in the novel Angels and Demons and its translation novel Malaikat and Iblis. Both of the novels become the process of describing metaphor that was completely used metaphor theory, then found the translation technique and assessment quality translation in them.

Data in this study were the metaphor expressions which found in the story of Angels and Demons and Malaikat dan Iblis as its translation novel in Indonesian language written by Isma B. Koesalamwardi. This research has three informants as the rater in every aspect of accuracy, acceptability and readability. It was used to make the data qualified and accurate in order to assessment the quality of translation.

According to Arikunto (1997: 225-235), instrument was the tool when the researcher

used a method so that instrument needed to get the data in a research. In this research, the researchers used questionnaire. 
The data collection technique in this study was metaphor expression in the novel Angles and Demons, it was taken by reading and comparing the novel with the translated version of the novel. The data was collected by sampling technique especially purposive sampling or criterion-based sampling, giving the data to the raters by questioner and interview in order to make the data valid, reliable and to get the rating of quality translation and then identifying the translation technique that was used in the novel Angel and Demons and its translation novel Malaikat dan Iblis, then submitting the data to get validation from the translation expert.

In analyzing the data, the researchers used three steps. There were classifying the types of metaphor in Angle and Demons and its translation novel Malaikat dan Iblis, based on Larson's classification, classifying the translation technique using Molina and Albir's theory and classifying the accuracy, acceptability and readability using Nababan's theory.

\section{FINDING AND DISCUSSION}

There were 119 data metaphor expressions found in the novel Angel and Demons with 35 data of dead metaphor and 84 data of live metaphor expressions. They used nine techniques of translation. Further, the result of analyzing data showed that metaphor translation in the novel Angels and Demons and its translation novel Malaikat dan Iblis written by Isma B. Koesalamawardi was qualified translation with the assessment 2.90 from the counting each raters of the data.

The following were the table presentation of the translation technique, the frequency usage and quality of the metaphor translation, also componential table and score of quality of translation from each aspect.

Table 1. Translation Technique and the Frequency Usage

\begin{tabular}{|c|l|c|c|}
\hline No. & Technique of Translation & Total Data & Percentage \\
\hline 1. & Literal Translation & 95 & $67.86 \%$ \\
\hline 2. & Adaptation & 22 & $15.71 \%$ \\
\hline 3. & Amplification & 11 & $7.86 \%$ \\
\hline 4. & Reduction & 4 & $2.86 \%$ \\
\hline 5. & Borrowing & 2 & $1.43 \%$ \\
\hline 6. & Compensation & 2 & $1.43 \%$ \\
\hline
\end{tabular}




\begin{tabular}{|c|l|c|c|}
\hline 7. & Established Equivalence & 2 & $1.43 \%$ \\
\hline 8. & Generalization & 1 & $0.71 \%$ \\
\hline 9. & Transposition & 1 & $0.71 \%$ \\
\hline \multicolumn{2}{r|}{ Total } & $\mathbf{1 4 0}$ & $\mathbf{1 0 0 \%}$ \\
\hline
\end{tabular}

Table 2. Quality of Translation

\begin{tabular}{|l|l|l|}
\hline \multicolumn{2}{|c|}{ Quality } & \multicolumn{1}{c|}{ Total } \\
\hline \multirow{2}{*}{ Accuracy } & Accurate & $112(99.16 \%)$ \\
\cline { 2 - 3 } & Less Accurate & $7(5.89 \%)$ \\
\hline \multirow{2}{*}{ Acceptability } & Acceptable & $112(99.16 \%)$ \\
\cline { 2 - 3 } & Less Acceptable & $7(5.89 \%)$ \\
\hline \multirow{2}{*}{ Readability } & High & $113(94.95 \%)$ \\
\cline { 2 - 3 } & Medium & $6(5.04 \%)$ \\
\hline
\end{tabular}

Table 3. Componential Table

\begin{tabular}{|c|c|c|c|c|c|c|c|c|c|c|c|c|c|c|c|c|c|c|}
\hline \multirow{3}{*}{$\begin{array}{c}\text { Types } \\
\text { of } \\
\text { Meta } \\
\text { phor }\end{array}$} & \multirow{2}{*}{\multicolumn{9}{|c|}{ Technique of translation }} & \multicolumn{9}{|c|}{ Quality of translation } \\
\hline & & & & & & & & & & \multicolumn{3}{|c|}{ Accuracy } & \multicolumn{3}{|c|}{ Acceptability } & \multicolumn{3}{|c|}{ Readability } \\
\hline & 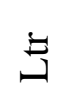 & $\frac{8}{4}$ & $\Xi$ & $\frac{U}{\tilde{\alpha}}$ & 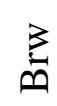 & $\Xi$ & $\begin{array}{l}\vec{n} \\
\tilde{I}\end{array}$ & 节 & 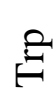 & 3 & 2 & 1 & 3 & 2 & 1 & 3 & 2 & 1 \\
\hline Dead & 22 & 9 & 3 & 1 & 1 & 1 & 2 & - & - & 34 & 1 & - & 33 & 2 & - & 32 & 3 & - \\
\hline Live & 73 & 13 & 8 & 3 & 1 & 1 & - & 1 & 1 & 79 & 5 & - & 79 & 5 & - & 81 & 3 & - \\
\hline Total & 95 & 22 & 11 & 4 & 2 & 2 & 2 & 1 & 1 & 113 & 6 & - & 112 & 7 & - & 113 & 6 & - \\
\hline
\end{tabular}

Table 4. Score Quality of Translation

\begin{tabular}{|c|c|c|c|}
\hline \multicolumn{4}{|c|}{ The Average score of Quality of translation } \\
\hline & Accuracy & Acceptability & Readability \\
\hline Live metaphor & 243,37 & 241,39 & 244,71 \\
\hline Dead metaphor & 103,34 & 101,74 & 102,01 \\
\hline Total & 346,71 & 342,74 & 346,71 \\
\hline Average & 2,91 & 2,88 & 2,91 \\
\hline \multicolumn{4}{|c|}{ Score Quality of Translation } \\
\hline Accuracy & Acceptability & Readability & Score \\
\hline $2,91 \times 3=8,73$ & $2,88 \times 2=5,76$ & $2,91 \times 1=2,91$ & $17,4: 6=\mathbf{2 , 9 0}$ \\
\hline
\end{tabular}

In this research, the researcher discussed about the Metaphor Translation in the Novel Angels and Demons by Dan Brown into Malaikat dan Iblis written by Isma B. Koesalamwardi as its translation. This research focused on metaphor translation, technique of translation and quality of translation. There were three previous studies of this research 
such as the first, Anwar (2015) entitled "An Analysis of Metaphor in American Gods Novel by Neil Giman". The researcher took a metaphor in American Gods by Neil Gaiman as the topic of the study. This research just identified the types and meaning of metaphor according to Larson's classification, and used connotative meaning. The second previous study was Qomariah (2015) entitled "The Analysis of Personification Translation in the Novel of Angels and Demons". The analysis started by the analysis of technique translation that was confronted by Molina and Albir (2002) and Moentaha (2006) then, continued with the quality of translation. The differences of Qomariah's research with this research was the theory of technique of translation and focused of the study. Qomariah's research used Molina and Albir (2002) and Moentaha (2006) but this research just used Molina and Albir (2002) of translation technique. In Qomariah's research, the focus of the study was personification translation, this research focused on metaphor translation. The third

previous study was Thahara (2014) entitled "Analisis Terjemahan Simile dalam Novel Angels \& Demons ke dalam Malaikat \& Iblis (Pendekatan Stilistika)". Thahara's research used Molina and Albir (2002) and Moentaha (2006). Thahara's research focused on simile translation but this research focused on metaphor translation.

\section{Cultural Values}

Metaphor as a part of figurative language could be a way of the authors or writers to express their ideas in a good diction and also as the identity of them. Metaphor was the expression of an understanding of one concept in terms of another concept, where there was similarity or correlation between the two. It was the understanding itself of one concept in terms of another. The translator must be smarter in shifting the message or main point of source language into target language in order to make the result of the translation to be accurate, acceptable and readable by the target readers based on their cultures and the rules of target language.

\section{CONCLUSION AND SUGGESTION}

The result of the study showed there were 119 data of metaphor expressions, which were 84 live metaphors and 35 dead metaphors. It used nine techniques of translation 
(literal translation, adaptation, amplification, reduction, borrowing, compensation, established equivalence, generalization and transposition). The dominant technique translation was literal translation with the total data of 95. And the score of quality of translation was 2.90. It meant that the quality of translation was good because the rater could understand the accuracy, acceptability and readability easily based on the culture and the meaning of the metaphor expressions.

The researcher realized that this research was still need the developments study of the used of technique translation and suggests that the next researchers can improve the finding problem of translation. This research could give more knowledge and references for the beginners of researchers about translation, technique of translation and quality of translation.

\section{REFERENCES}

Arikunto, Suharsimi. (1997). Prosedur Penelitian: Suatu Pendekatan Praktik. Jakarta: Rineka Cipta.

Brown, Dan. (2009). Angels and Demons. New York: 1230 Avenue of the Americas.

Budianto, L and Fardhani, A.E. (2010). A Practical Guide for Translation Skill. Malang: UIN Maliki Press.

Chaer, Abdul. (2007). Linguistik Umum. Jakarta: Penerbit Rineka Cipta.

Fatima, Yasmine Rachma. (2008). An Evaluation on the Translation into Indonesian the English Idioms in the Spoken Text of E.B White's Charlotte's Web. Thesis. Jember: Faculty of Letters, Jember University.

Fatoni, Arif. (2008). An Analysis of Figurative Language on the Cold Play's Songs in Album " $X \& Y$ ". Thesis. Jember: Faculty of Letters, Jember University.

Gunawan, Imam. (2014). Metode Penelitian Kualitatif: Teori dan Praktik. Jakarta: PT. Bumi Aksara.

Goatly, A. (1997). The Language of Metaphor. New York: Routladge.

Hatim, Basil and Munday, J. (2004). Translation an Advanced Resource Book. New York: Routledge. 
Keraf, Gorys. (2009). Diksi dan Gaya Bahasa. Jakarta: PT Ikrar Mandiriabadi.

Koesalamwardi, Isma B. (2006). Malaikat dan Iblis. Jakarta: PT. Serambi Ilmu Semesta.

Kristianto, Hadi. (2011). A Translation Analysis of English Text to Indonesian Text in the Movie Script of "Oliver twist". Thesis. Jember: Faculty of Letters, Jember University.

Lakoff, George. (1994). What is metaphor. In J. A. Barnden and K. J. Holoyak, editors, Advancesin Connectionist and Neural Computation Theory: Analogy, Metaphor and Reminding, Norwood, NJ. Ablex.

Lakoff, George, and Mark Johnson. (1980). Metaphors We Live By. Chicago: University of Chicago Press.

Larson, Mildred. (1998). Meaning Based Translation. USA: University Press of America.

Lotfipour, Kazem and Saedi. (1992). "Analysing Literary Discourse: Implications for Literary Translation”.Meta: journal des traducteurs/Meta: Translators' Journal, vol. $37, \mathrm{n}^{\circ} 2,1992$, p. 193-203.

Matthews, P.H. (1997). The Concise Oxford Dictionary of Linguistics. New York: Oxford University Press.

McArthur, Tom (ed). (1992). The Oxford Companion to the English Language. New York: Oxford University Press.

Moleong, Lexy J. (2012). Metodologi Penelitian Kualitatif. Bandung: PT. Remaja

Molina, L and Hurtado, A. (2002).“Translation Techniques Revisited”. Journal Meta, XLVII, 4, 2002.

Mustafa, Anwar. (2015). "An Anaysis of Metaphor in American Gods Novel". Thesis. Situbondo: Faculty of Letters, University of Abdurachman Saleh Situbondo.

Nababan, Nuraeni \& Sumardiono. (2012). "Pengembangan Model Penilaian Kualitas Terjemahan”. Jurnal Kajian Linguistik dan Sastra, Vol 24. No.1, June 2012: 39-57.

Qomariah, Lia Rosdiana. (2015). "The Anaysis of Personification Translation in the Novel of Angles and Demons". Thesis. Situbondo: Faculty of Letters, University of Abdurachman Saleh Situbondo.

Tarigan, Henry Guntur. (1990). Pengajaran Gaya Bahasa. Bandung: Offset Angkasa. 
Tarigan, Henry Guntur. (1990). Pengajaran Semantik. Bandung: Offset Angkasa.

Teilanyo, Diri I. (2007). "Figurative Language in Translation: A Study of J.P. Clark's the Ozidi Saga". Meta: Journal des traducteurs/Translators' Journal, vol. 52, n 2, 2007, p. 309-326.

Thahara, Yopi. (2014). Analisis Terjemahan Simile dalam Novel Angels and Demons ke dalam Malaikat dan Iblis. Thesis. Surakarta: Program Study of Linguistic Translation, Sebelas Maret University.

Venuti, Lawrence. (2002). The Translation Study Reader. London: Routledge.

\section{Internet:}

Brown, Dan, Inc. (2013) The Official Website of Dan Brown http://www.danbrown.com/\#author-section. Accessed on May 13 ${ }^{\text {rd }}, 2015$ at 02.30 PM

Merriam-Webster, Incoporated. (2015). An Encyclopædia Britannica Company http://www.merriam-webster.com/dictionary/methodology. Accessed on May 13 ${ }^{\text {rd }}, 2015$ at $02.40 \mathrm{PM}$

Oxford University Press. (2015). Oxford Dictionaries Language Matters http://www.oxforddictionaries.com/definition/english/novel. Accessed on May $13^{\text {rd }}, 2015$ at $02.35 \mathrm{PM}$

X, J Kennedy. (1983). Literature: An Introduction to Fiction, Poetry, and Drama. Toronto: Little Brown Company 